\title{
An assessment of urban vulnerability in the Amazon Delta and Estuary: a multi-criterion index of flood exposure, socio-economic conditions and infrastructure
}

\author{
Andressa V. Mansur ${ }^{1,3}$ - Eduardo S. Brondízio ${ }^{2,3} \cdot$ Samapriya Roy $^{3,4}$. \\ Scott Hetrick ${ }^{3}$ Nathan D. Vogt ${ }^{3,5} \cdot$ Alice Newton $^{6,7}$
}

Received: 7 August 2015/ Accepted: 23 February 2016/Published online: 14 March 2016

(C) Springer Japan 2016

\begin{abstract}
The Amazon Delta and Estuary (ADE) is a region of continental and global ecological importance. Controversy, many of the basic infrastructure and services essential for quality of life and sustainable development of this delta are absent. Using a conceptual model to define socio-economic vulnerability in the urban ADE, a thorough assessment of indicators including sanitation services, housing conditions, household income, population, flood risk and unplanned settlements was conducted in 41 cities at the census sector scale $(n=2938)$. A multi criterion index was applied to classify urban vulnerability from three
\end{abstract}

Handled by Sylvia Szabo, University of Southampton, Southampton, United Kingdom.

Electronic supplementary material The online version of this article (doi:10.1007/s11625-016-0355-7) contains supplementary material, which is available to authorized users.

Andressa V. Mansur

andressavmansur@gmail.com

1 Oficina Erasmus Mundus, Universidad de Cádiz, Puerto Real 11519, Cádiz, Spain

2 Department of Anthropology, Center for the Analysis of Social-Ecological Landscapes (CASEL) and the Ostrom Workshop, Indiana University, Bloomington, IN 47405, USA

3 Center for the Analysis of Social-Ecological Landscapes (CASEL), Indiana University, Bloomington, IN 47405, USA

4 Department of Geography, Indiana University, Bloomington, IN 47405, USA

5 INPE-National Institute of Spatial Research, São José dos Campos, Brazil

6 NILU-CEE, Box 100, 2027 Kjeller, Norway

7 CIMA, Gambelas Campus, University of Algarve, 8005-139 Faro, Portugal dimensions: flood exposure, socio-economic sensitivity and infrastructure. This is the first study to examine urban vulnerability within and between urban areas of the ADE. Results indicated that most of the urban sectors of the ADE are exposed to potential risks due to a combination of flood hazards, poverty and basic structural deficiencies such as insufficient drinking water or inadequate waste water collection, with several sectors being afflicted by similar problems. The assessment of vulnerability indicates that $60-90 \%$ of the urban population live in conditions of moderate to high degree of vulnerability. The ADE cities presented a pattern where vulnerability increases from city center to their newly developed urban areas. Inadequate planning coupled with rapid urbanization has contributed to the development of unplanned settlements in almost half of the urban sectors of the ADE. Combined, these factors contribute to widespread socio-economic vulnerability along the urban spaces of the ADE, increasing exposure to health risks and more frequent seasonal and stochastic events such as storm surges and high flooding levels.

Keywords Amazon - Delta · Estuary · Vulnerability · Indicators · Index · Socio-economic · Households · Urban sectors · Sanitation · Urban density · Flooding · Unplanned settlements

\section{Introduction}

Deltas are complex socio-ecological systems (SES), exposed to multiple pressures, both anthropogenic and environmental, including climate change (Brondizio et al. this issue). The combined effect of these pressures increases the vulnerability of SES and results in varied risks to the inhabitants of the different segments of delta 
systems, impacting the social and economic development of these areas (Overeem and Syvitski 2009; Vörösmart et al. 2009; Foufoula-Georgiou et al. 2013). Currently, deltas are considered hotspot systems to detect, monitor and quantify the socio-environmental changes related to natural hazards and disasters such as flooding, subsidence, coastal erosion, cyclones, and sea-level rise (Crossland et al. 2005; Newton et al. 2012; Newton and Weichselgartner 2014; Szabo et al. 2015; Tessler et al. 2015). Climate change exacerbates the existing vulnerabilities, which then aggravates social inequalities in tropical deltas regions (Szabo et al. 2015). While scientific advances provide for a better understanding of the function and vulnerabilities of deltas (Day et al. 1997; Syvitski 2008; Van der Most et al. 2009; Syvitski et al. 2009; Tejedor et al. 2015a, b; Tessler et al. 2015), further efforts are needed to scale down global prognostic models to regional and local level of analysis (Szabo et al. 2015). Local vulnerability assessments provide a more robust framework than comprehensive global assessments (Kasperson et al. 2005). Defining boundary to analyze vulnerability of a delta as a coupled SES can better inform development of policies and planning as needed at a local level with the prospects of shaping a sustainable future for delta regions (Szabo et al. 2015; Brondizio et al. this issue).

This study aims to assess vulnerability within and between urban areas in the Amazon Delta and Estuary (ADE) quantifying vulnerability using a multi-criterion index composed of three dimensions: flood risk exposure, urban infrastructure and socio-economic sensitivity.

The main objectives are:

1. assess different aspects of human well-being measured by indicators of sanitation services, housing conditions, income, population, areas under risk of flooding and unplanned settlements;

2. develop a multi-criterion index to measure socioeconomic vulnerability of the urban ADE;

3. quantify the three dimensions of vulnerability to classify the overall vulnerability of urban sectors.

To achieve these objectives, the indicators were collected from public databases at the census sector scale, the most disaggregated level of analysis of census data (defined in "Unit of analysis"). The methodology makes use of Shuttle Radar Topography Mission (SRTM) elevation data to characterize the flood risk sectors along the urban spaces of the ADE, and a composite index using the analytical hierarchy process (AHP) was developed for assessing the vulnerability of urban sectors within the ADE.

The results allowed us to explore and discuss the following research questions related to the vulnerability in the urban ADE:
1. How many people are under risk of flooding in the urban ADE?

2. How many people live in unplanned settlements and are under risk of flooding in these urban areas?

3. Which factors exacerbates the existing vulnerabilities in the urban ADE?

\section{Variability and change in the Amazon Delta and Estuary}

Geographical setting The ADE is the mouth of the world's largest river basin, with a drainage area of about 6 million $\mathrm{km}^{2}$ (Cohen et al. 2008). This tropical delta is tide-dominated (Hori and Saito 2007), and characterized by a series of distributaries and islands between the states of Amapá and Pará, in the northern region of Brazil. The ADE is formed by two main parts: the Amazon River mouth representing the North Channel and Marajó Bay representing the South Channel. The physical characteristics and morpho-dynamic processes in the North Channel are influenced by the tidal flood dynamics of the mouth of the Amazon River. The South Channel is influenced by tidal flood dynamics at the mouth of the Tocantins River, which also receives a small contribution from the Amazon River that flows to the south through the Para River and the Tocantins (Eisma et al. 1997; Vogt et al. 2015). The region is dominated by a meso-macro tidal regime, with a spring tide range of about $4 \mathrm{~m}$ (Eisma et al. 1997; Cohen et al. 1999). Large spring tides and heavy rainfall events control the periodicity, occurrence and extent of floods in the ADE.

The SES in the study includes the whole river delta and estuary, within and around Marajó Island, and a $5 \mathrm{~km}$ buffer of the ADE, as defined by Ericson et al. (2006) (see Fig. 3).

Climate and climate change The regional climate is tropical, warm and humid, with an average annual rainfall ranging around 2000-3000 mm (Figueroa and Nobre 1990). There are two well-defined seasons: a wet season from December to May with average rainfall exceeding $10 \mathrm{~mm}$ day per day, and a drier season with average rainfall below $2 \mathrm{~mm}$ day per day (Marengo et al. 2001). Both tidal and seasonal floods affect the ADE floodplain. Cyclones, storm surges and subsidence are not observed in the ADE, in contrast with other delta systems (Syvitski et al. 2009). Nevertheless, climate change, especially changes in precipitation and droughts, is predicted to affect the regional forest, the local economy and intensify the severity of the tropical floods in the delta (GeoAmazonia 2009; Fearnside 1995). The present contraction of the mangrove vegetation in the ADE is mainly due to a rise in the relative sea level, demonstrating that this region is very 
vulnerable to the impacts of the global environmental changes (Cohen and Lara 2003; França et al. 2012). Such changes will pace the ADE into a future space of elevated risk, where extreme events are more likely to occur, more people are exposed to flooding and a higher vulnerability is expected by more harm and losses caused by exposure (Tessler et al. 2015).

Human geography and demographics The ADE is located in a reserve of worldwide importance, described by Silva (2011) as "one of the most pristine and ecologically rich natural places on the planet". The ADE has been classified as "not at risk" due to relatively low river damming, as well as low water, gas and oil extraction (Overeem and Syvitski 2009; Syvitski et al. 2009) and "low flood risk" in terms of expected loss caused by flood events (Tessler et al. 2015). Global models using global data sets are limited in explaining vulnerability and risk at the regional and local perspectives. Besides, this delta is projected to change in the near future due to an accelerated and poorly planned urban expansion and economic development for the region (GeoAmazonia 2009; Brondizio et al. this issue), with consequences to the ecosystems services provided by the delta estuary. This includes the expansion of roads and fluvial transportation, ports, dams and mining (Brondizio 2013). The population of the ADE is projected to grow by more than $50 \%$ over a 10-year period (Overeem and Syvitski et al. 2009), making the delta particularly vulnerable to rapid human induced changes (Brondizio 2013). In addition, the population growth and the intensification of human activities are not accompanied by the implementation of the basic infrastructure required to support sustainable development and human well-being. As with other tropical deltas, urban infrastructure is lacking, medical care is deficient, employment is limited and urban population are subjected to periodic floods (Costa and Brondizio 2011; Guedes et al. 2012). Population growth exacerbates the lack of infrastructure and economic opportunities in these urban spaces (Costa et al. 2011). When combined, all these factors greatly aggravate the effects of hazardous events on local populations, increasing the social, economic and ecological vulnerability of the ADE and impacting well-being of population in this region.

\section{Definitions and conceptual model of vulnerability}

Deltaic systems are often exposed to multiple hazards (Syvitski et al. 2009), which vary according to specific ecological and social circumstances. The term vulnerability is broadly used in different social, economic, environmental contexts (Luers 2005; Newton and Weichselgartner 2014; Tapsell et al. 2010), different policy contexts, as well as different systems exposed to multiple hazards, reflecting the diversity of conceptualizations for vulnerability (Füssel 2007).

Chambers (1989) refers to vulnerability as "exposure to contingences and stress, and the difficult in coping with them". Although there is considerable variety in existing frameworks, vulnerability is often determined in time as a resultant of: (1) exposure to a hazard, stress and perturbations, (2) the sensitivity of people, places, and ecosystems to stress or perturbation, including their capacity to cope with stress; (3) the adaptive capacity of the system to changing conditions (Chambers 1989; Turner et al. 2003; Luers 2005; Kasperson et al. 2005; Adger 2006; IPCC 2014; Su et al. 2015).

Laukkonen et al. (2009) argues that the vulnerability of individuals and communities to the impacts of hazardous events are determined not only by the location of their settlements, but also by how the settlements are serviced, how effective and capable their local governments are and the adaptation capacity of their communities. The same author stresses that an analysis of vulnerability without considering social and economic aspects would be inappropriate in cases such as the ADE, where a significant proportion of the population lives below or at the poverty income level and lacks basic sanitation and urban infrastructure, such as safe drinking water, sewers, waste water treatment and appropriate solid waste disposal.

In this paper, the vulnerability analysis in the urban ADE is conceptualized as a function of three interconnected dimensions (Fig. 1): the exposure of population and urban areas to flood hazard (i.e., population density in flood risk areas), the socio-economic sensitivity (i.e., household income, settlement conditions, sensitive age groups), and the urban infrastructure (i.e., service and sanitation infrastructure provisioning and housing conditions), which in turns determines the adequate capacity for household adaptation and resilience within a given urban space. Our conceptual model also acknowledges the impact of these conditions on ecosystem services, which in turn may also modulate interactions between environmental hazards and different sectors of the urban population in the ADE (see Fig. 1). This conceptual model combines concepts, variables and feedbacks previously outlined in the vulnerability framework of Turner et al. (2003), ecosystem services and flood regulation from Guenni et al. (2005) and Kasperson et al. (2005) and the urban vulnerabilities and adaptation framework from Revi et al. (2014) and McGranahan et al. (2005).

To understand the vulnerability in the urban ADE, it is important to understand the process of urbanization that has shaped the cities within the ADE. During the 1970s and 1980s, the Brazilian government promoted a series of programs to stimulate economic development in the Amazon and to mitigate demographic pressures in other 


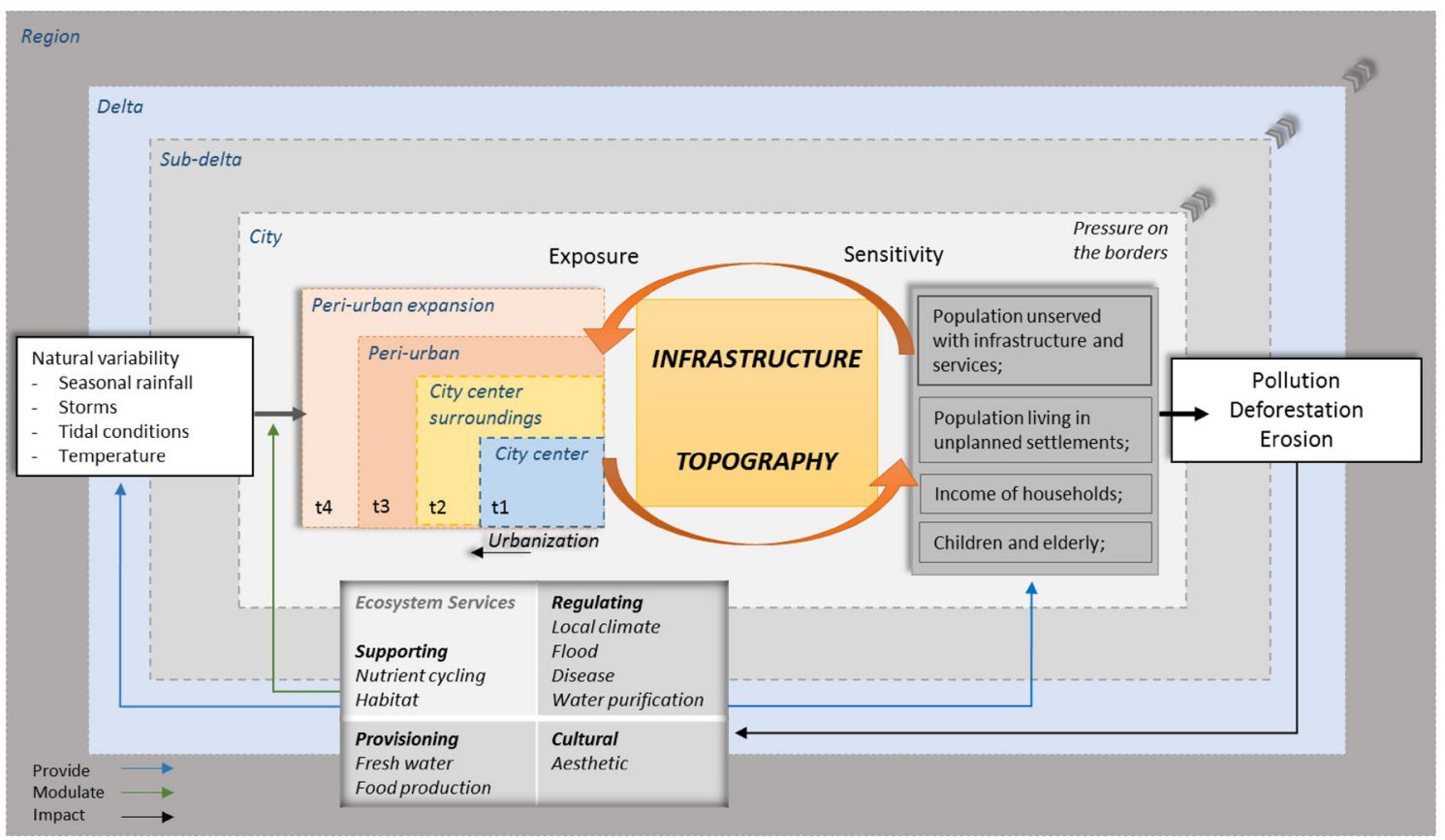

Fig. 1 The conceptual model of vulnerability in the urban Amazon Delta and Estuary

parts of Brazil (Guedes et al. 2009; Barbieri et al. 2009). Along with other social and economic changes affecting the region, these initiatives contributed to rapid urban population growth that exceeds the levels of local economic development necessary to support it (Browder and Godfrey 1997). Today, about $79 \%$ of the ADE population live in urban areas with poor or inexistent infrastructure, and this trend continues to increase (see Costa and Brondizio 2009; Brondizio et al. this issue). In the $\mathrm{ADE}$, as in other parts of the Amazon, urban growth has taken place particularly in flood-prone areas and unplanned settlements (Browder and Godfrey 1997; Benatti 2011). Municipal and state governments in the region have been unable to address the growing deficit in infrastructure and services provisioning to an expanding urban population.

As suggested by the conceptual framework (Fig. 1), the level of access to public services and urban infrastructure correlates with age and location of settlements and neighborhoods (Perz 2000). Service provisioning usually starts with water distribution and electricity (involving both public provisioning and illegal connections). While many sectors are served with basic garbage collection services, a significant part of the solid waste is discarded in public spaces and streams, affecting significantly local ecosystem services. Infrastructures requiring large-scale investments and maintenance costs, such as sewer collection and treatment, and street paving are mostly restricted to older urban sectors.
Floods in the ADE are driven mainly by rainfall patterns in the region and in different parts of the basin and their interaction with daily and monthly tidal cycles. The region has a dense network of interconnected streams, known as igarapés which strongly influence flood dynamics along the urban ADE (Pinedo-Vasquez et al. 2011). Floods episodes vary in influence across a gradient of elevation in the urban ADE (Benatti 2011). The damage caused by flood hazards will vary from place-to-place depending on topography, stream sedimentation, solid waste and flow capacity, human exposure and the level of infrastructure and services of urban spaces (Adger 2006; Turner et al. 2003).

A significant portion of the rural and urban populations of the ADE depend directly on local ecosystems goods and services, including the provision of water for home consumption and personal hygiene, fishing, and transportation. Ecosystem regulating services, such as ability to absorb and diffuse tidal waters provide protection from the adverse consequences of flood hazards on the well-being of population (Guenni et al. 2005).

Conversely, the impacts of urbanization directly and indirectly impact ecosystems services (Guenni et al. 2005). Urban pollution, accelerated riparian deforestation and growing demand for resources are exerting increasing pressures on local ecosystem services (Guenni et al. 2005; McGranahan et al. 2005; Brondizio et al. this issue). Lowincome groups are often disproportionately vulnerable because of their reliance on natural resources, poor housing 
conditions in areas of high exposure to flood, and limited access to health services (Revi et al. 2014).

\section{Materials and methods}

\section{Urban spaces of the Amazon Delta and Estuary}

The urban spaces located within the ADE study area are a mosaic of coastal communities, some small urban areas and two metropolitan areas, including the oldest urbanized areas in the Brazilian Amazon (Costa and Brondizio 2011). There are 2938 urban sectors within 41 municipalities (see Fig. 3) with an urban population of almost 3 million people from about 760,000 households spread along the delta floodplain (IBGE 2010). For the study, the urban sectors were sub-divided into three regions:

1. Small urban spaces (SUS);

2. Belém Metropolitan Region (BMR), and;

3. Macapá Metropolitan Region (MMR).

The small urban spaces (SUS) are located within and around Marajó Island, spread along the delta floodplain and inland areas. The SUS are important in the regional context because they maintain a strong link with rural areas (Guedes et al. 2009; Costa and Brondizio 2011). The SUS is comprised of 462 urban sectors accounting for about $16 \%$ of the sectors within the urban ADE, composed of 34 Municipalities: Abaetetuba, Acará, Afuá, Almeirim, Anajás, Bagre, Barcarena, Breves, Cachoeira do Ariri, Cametá, Chaves, Colares, Curralinho, Curuçá, Gurupá, Iguapé-Miri, Itaubal, Limoeiro do Ajuru, Mazagão, Melgaço, Mocajuba, Muaná, Oeiras do Pará, Ponta de Pedras, Portel, Porto de Moz, Salvaterra, Santa Cruz do Ariri, Santo Antônio do Tauá, São Caetano de Odivelas, São João da Ponta, São Sebastião da Boa Vista, Soure and Vigia.

The Belém Metropolitan Region (BMR) is in the eastern part of the ADE, at the mouth of Guamá River, in the Brazilian Federal State of Pará. The BMR is the administrative capital of the South Channel region and the largest metropolitan area in the Amazonian region, with an urban population of approximately two million inhabitants (IBGE 2010). The BMR is comprised of 1931 urban sectors within five Municipalities: Ananindeua, Belém, Benevides, Marituba and Santa Bárbara do Pará. The BMR contains the majority of the urban sectors and population, accounting for $67 \%$ of the urban population within the ADE.

The Macapá Metropolitan Region (MMR) is located in the North Channel, adjacent to the lower Amazon River, in the Federal State of Amapá. This metropolitan region has an urban population of 500,000 , the largest urban population of Amapá, and is the administrative center for the municipalities of the North Channel. The MMR comprises
545 urban sectors within two municipalities: Macapá and Santana. About $18 \%$ of the ADE urban sectors are in the MMR.

According to Costa and Brondizio (2009), independent of age, size and location of the urban spaces of the ADE, the expansion of the cities followed similar trajectories, including the unplanned expansion along river borders and low lying areas and the deficiencies in urban infrastructure and services and lack of employment base.

\section{Data collection}

\section{Unit of analysis}

The present study includes 2938 census sectors, delimited by the 2010 demographic census as urban sectors. The Brazilian Institute for Geography and Statistics (IBGE) defines census sectors as the minimum units of area created for the purpose of cadastral surveys, taking into consideration the geographical extent, political-administrative divisions and territorial interest (IBGE 2010). The sectors are classified as "rural" or "urban" by IBGE.

The research focused on the urban sectors classified by IBGE (2010) as:

1. urbanized areas inside cities;

2. isolated urban areas, and;

3. urban extent in rural areas.

Eighteen urban sectors within the study area were excluded from our analysis due to missing data. Urban sectors and data for indicators at household level were organized using Arc-GIS 10.2.2.

\section{Selected indicators for vulnerability assessment}

The indicators selected from the 2010 demographic census (IBGE 2010) for the vulnerability assessment are summarized in Table 1 . They were chosen to represent the three dimensions of vulnerability discussed in "Definitions and conceptual model of vulnerability". The appropriate indicators selected were based on literature review followed by both the applicability of our vulnerability model and data accessibility at census sectors scale. These indicators were confirmed and expanded following a consultation workshop for vulnerability analysis in the ADE held in the city of Belem in 2015 in collaboration with several partner institutions. Reasons for indicators were briefly explained in the following section.

1. Exposure dimension: exposure refers to entities (population, urban areas) being exposed to the impacts of flood hazards) (WRR 2014). Chosen indicators were, therefore, the sectors located in areas of low elevation 
Table 1 Indicators divided in groups according to the vulnerability dimensions

\begin{tabular}{|c|c|c|}
\hline Dimension & Indicator group & Indicators \\
\hline Exposure & Flood risk exposure & $\begin{array}{l}\text { Population under risk of flooding } \\
\text { Area under risk of flooding }\end{array}$ \\
\hline \multirow[t]{3}{*}{ Socio-economic sensitivity } & Household income & $\begin{array}{l}\text { No income and income less than one minimum wage } \\
\text { Income less than five and more than one minimum wage }\end{array}$ \\
\hline & Population age groups & Children $(<10$ years old) and elderly ( $>65$ years old) \\
\hline & Location & Population living in unplanned settlements \\
\hline \multirow[t]{2}{*}{ Infrastructure } & Sanitation services & $\begin{array}{l}\text { Households with public water supply } \\
\text { Households served by solid waste collection } \\
\text { Households with domestic effluent piped to a sewer system }\end{array}$ \\
\hline & Housing conditions & $\begin{array}{l}\text { Households without drainage system } \\
\text { Households with accumulating solid waste in front of the house } \\
\text { Households with incidence of open-air sewage } \\
\text { Area considered unplanned settlement }\end{array}$ \\
\hline
\end{tabular}

that are under risk of flood, explained in the next section of this paper, and the percentage of population who are exposed to flooding.

2. Socio-economic sensitivity dimension: the distribution of the impacts of extreme events is not uniform across the delta. There are groups of urban dwellers that are more sensitive, facing higher risks, such as illness, mortality, damage to or loss of homes and assets, disruption to incomes (Hardoy and Pandiella 2009). For instance, elderly population and children may face serious health risks when water supplies are contaminated by flooding (Revi et al. 2014). The impact is also greater in low income groups and informal settlements as they are typically more exposed to flood hazards with limited or no hazardreducing infrastructure, low-quality housing, and limited capacity to cope (Guenni et al. 2005; Revi et al. 2014).

Three groups of indicators were selected to represent these aspects: Household monthly income, sensitive age groups and population located in unplanned settlements. Two categories of households monthly income were computed in the index: households with no income and with income less than one-fifth of the necessary income (less than one minimum wage) and households with more than one minimum wage but less than the necessary income (income between one and five minimum wage) (DIEESE 2015). The Federal Constitution of Brazil, in Article $7^{\circ}$, states that the income considered necessary is the one that attends to the basic needs of the individual and family such as: residence, food, education, healthy, laser, clothing, hygiene, transport and social security.
Unplanned settlements are those sectors coded as subnormal agglomerations in the 2010 census. Many definitions and terms are used to refer to unplanned settlements, for example: informal settlements, squatter settlements, marginal settlements, unconventional dwellings, non-permanent structures, inadequate housing, slums, and shantytowns, among others (WHO 2003). In our study, subnormal agglomerations are groups of at least 51 household units, lacking in public services, with no planning and situated in areas considered as inappropriate, with no legal instrument of land ownership. They include slums known as favelas or baixadas, unauthorized construction (land invasion), floodplains and houses on stilts (IBGE 2010). In the case of the ADE, these sectors are usually located in low land areas, with no legal claim, often lacking in public services, urban infrastructure and other basic human necessities. The streets typically have open sewers and accumulations of solid waste.

3. Infrastructure dimension: this dimension encompasses both sanitation services and housing conditions of urban areas. Such indicators represent the level of availability of public services and infrastructure in the urban ADE and allow us to analyze another aspect of sensitivity closely related to coping capacity of urban spaces (Laukkonen et al. 2009). Sensitivity here relates to the fragility of settlements and structural factors which make people or systems susceptible to the impacts of floods, for instance the incidence of openair waste water inside a plot or yard. While coping capacity comprises of measures and abilities that are immediately available to reduce harm and damages in the occurrence of an event (WRR 2014), including 
public water supply and domestic effluent piped to a sewer system. Incidence of open-air waste water can coexist with situations where households are connected to a sewer system, as well as the accumulation of solid waste in front of the house can co-exist with situations where households are served by solid waste collection.

Finally, Spearman's correlation analysis was performed to explore the relationships between indicators. Since our variables were not normally distributed and an important presence of outliers was observed, we chose a non-parametric test to explore this relationship.

\section{Characterization of areas at risk}

The characterization of areas at risk was based on the surface elevation of the ADE. The data set for this characterization include a shapefile of census sectors for 2010 provided by IBGE, a SRTM raster file with a spatial resolution of approximately 30 meters and a shapefile of areas defined as ressacas in the cities of Macapá and Santana for 2012, provided by the IEPA (Institute for Scientific and Technological Researches of the state of Amapá). Ressacas are "fluvial physical systems, drained by freshwater and connected to a main stream, strongly influenced by rainfall and herbaceous vegetation" (Takiyama et al. 2012). The shapefile of ressacas areas are classified in three classes:

1. ressacas pluvial;

2. ressacas pluvial and tidal, and;

3. várzea pluvial and tidal.

Since the ressacas areas are inundated seasonally, we consider both the ressacas and várzeas as flood risk areas.

The SRTM-30 m data pixels with an elevation of zero, negative or missing values were deleted to avoid areas that correspond to water features, or other sources of interference. Zonal statistics for the ressacas areas and census sectors were extracted from the SRTM-30m raster file, calculating the pixels statistics: mean, majority, maximum, median, minimum, minority, range, standard deviation, summary, and variety, minimum and maximum). These procedures were performed using ERDAS IMAGINE 2013 and ArcGIS 10.2.2.

To classify the flood risk areas, ressacas and the census sector data set were compared. Ressacas classified as várzea (pluvial and tidal) had a mean pixel value of 10 and a majority value of 6 . Sectors within the ADE with mean pixels $\leq 10$ or majority $\leq 6$ that aligned well with these ressacas were determined to be under risk of flooding in an extreme water level event. Such events are the episodes of floods that occur during the rainy season when the rain is combined with the maximum tide (Takiyama et al. 2012).

\section{Vulnerability index}

Figure 2 represents the index developed for assessing vulnerability of the urban sectors within the ADE, as well as the Analytical Hierarchy process (AHP) used to assign weightings to each individual indicator and to the three dimensions of vulnerability. The AHP has become a critical tool which has been applied toward understanding decisions which are based on multi criterion analysis. The method has been tested extensively over the span of more than three decades and has been determined to be an effective evaluation tool for assessing criterions and opinions which need to be weighted (Saaty 1980, 2008). The AHP allows the user to develop a hierarchy of priorities and to minimize the number of factors that are being dealt with at each hierarchical level.

In our index, the indicators were initially classified either as increasing vulnerability indicator $\left(\mathrm{V}^{+}\right)$whose increasing value enhances vulnerability or reducing vulnerability indicator $\left(\mathrm{V}^{-}\right)$whose increasing value contributes to the resilience of the system. The AHP level 1 analysis looks at establishing inter indicator hierarchies for each exposure separately. The pair wise comparison was established using the correlationship between each variable to the other and then converting them into Saaty's scale. Once these are established, the weights associated with each dimension of vulnerability can be calculated using the following equations (for $\mathrm{V}^{+}$or $\mathrm{V}^{-}$).

AHP level 1:

$\left(\mathrm{V}^{+}\right)$Level 1 Vulnerability dimension

$$
=\sum_{i=1}^{n}\left(\text { Weight }_{i} \times \text { Indicator }_{i}\right)
$$

$\left(\mathrm{V}^{-}\right)$Level 1 Vulnerability dimension

$$
=\sum_{i=1}^{n}\left[1-\left(\text { Weight }_{i} \times \text { Indicator }_{i}\right)\right]
$$

The process in level 2 now established comparative priorities or weights between the three different dimensions and establishes a final overall vulnerability for each sector in the region.

AHP level 2:

Level $2=\sum_{i=1}^{n}\left(\right.$ Weight $_{i} \times$ Level 1 Vulnerability dimension $\left.{ }_{i}\right)$

Overall vulnerability $\left(O_{\mathrm{v}}\right)$ :

$$
\begin{aligned}
O_{\mathrm{v}}= & W_{\text {Exp }} \times \text { Level } 2(\text { Exposure })+W_{\text {se }} \\
& \times \text { Level } 2(\text { SE Sensitivity })+W_{\text {inf }} \\
& \times \text { Level } 2(\text { Infrastructure })
\end{aligned}
$$




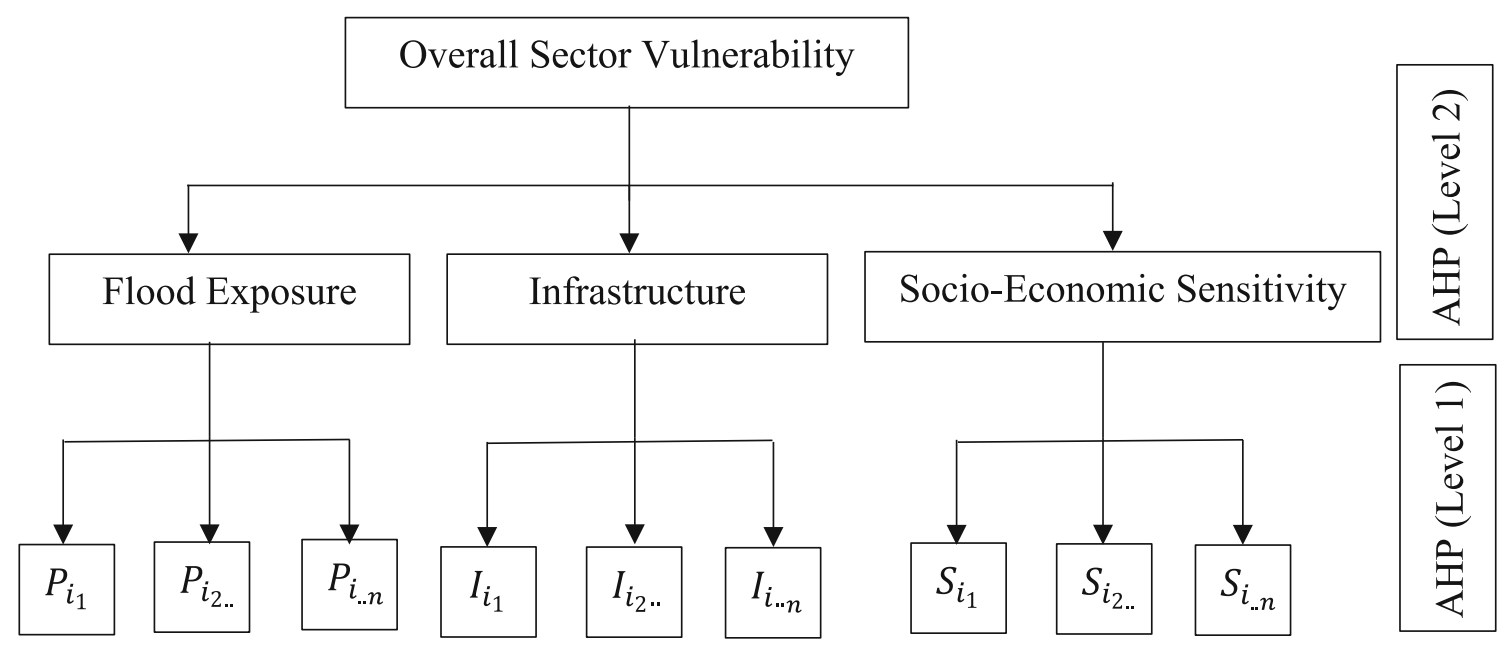

$$
\begin{aligned}
& P_{i_{n}}-\text { Indicators of Flood Exposure } \\
& I_{i_{n}}-\text { Indicators of Infrastructure } \\
& S_{i_{n}}-\text { Indicators of Socio - Economic Sensitivity }
\end{aligned}
$$

Fig. 2 Scheme of vulnerability assessment and analytical hierarchy process (AHP) used to weight indicators

Here, Exp refers to flood exposure, $\mathrm{SE}=$ refers to socio-economic sensitivity, inf refers to infrastructure, established at AHP level 2.

The pair wise comparison develops consistent method and a consistent judgement criterion for establishing relative priorities or weights at multiple levels. The overall vulnerability value vary from 0 (low vulnerability) to 1 (high vulnerability), and the weights represent the percentage contribution of each factor towards generating the overall vulnerability for the area. (For example, our final weight for the three dimensions, AHP level 2, were 0.1 for flood exposure, 0.2 for socio-economic sensitivity and 0.7 for infrastructure).

\section{Results and discussion}

The results were divided into four parts. The first section describes the results obtained from the assessment of sectors under risk of flooding and unplanned settlements, paying particular attention to the population at risk. The second section presents the assessment of individual indicators, focusing on household income, population age groups, sanitation services and housing conditions. The third section presents the vulnerability index assessment for the urban sectors of the ADE.

\section{Assessment of flood risk areas and unplanned settlements}

The distribution of the urban sectors along the ADE is shown in Fig. 3. The sectors are classified as:

1. under risk of flooding;

2. considered unplanned settlements;

3. both situations (under risk of flooding and considered unplanned settlement), and;

4. neither situation.

More than 1.2 million people representing $41 \%$ of the total urban population are exposed to risk of flooding in extreme water level events. Of these people at risk, 307,392 live in the SUS, 686,347 live in the BMR and 239,660 live in the MMR (Fig. 4). About $41 \%$ of the total urban population lives in unplanned settlements. Over 1.1 million people in the BMR are living in unplanned settlements, while MMR and SUS together reaches almost hundred thousand inhabitants. Results indicate that about half million people or $19 \%$ of the population under risk of flooding are also living in unplanned settlements, mostly in the BMR (see Fig. 4).

Floods are a natural process in the Amazon but also the main natural hazard posing the greatest threat to the urban population in the ADE (CEPED UFSC 2012). Severe flood 


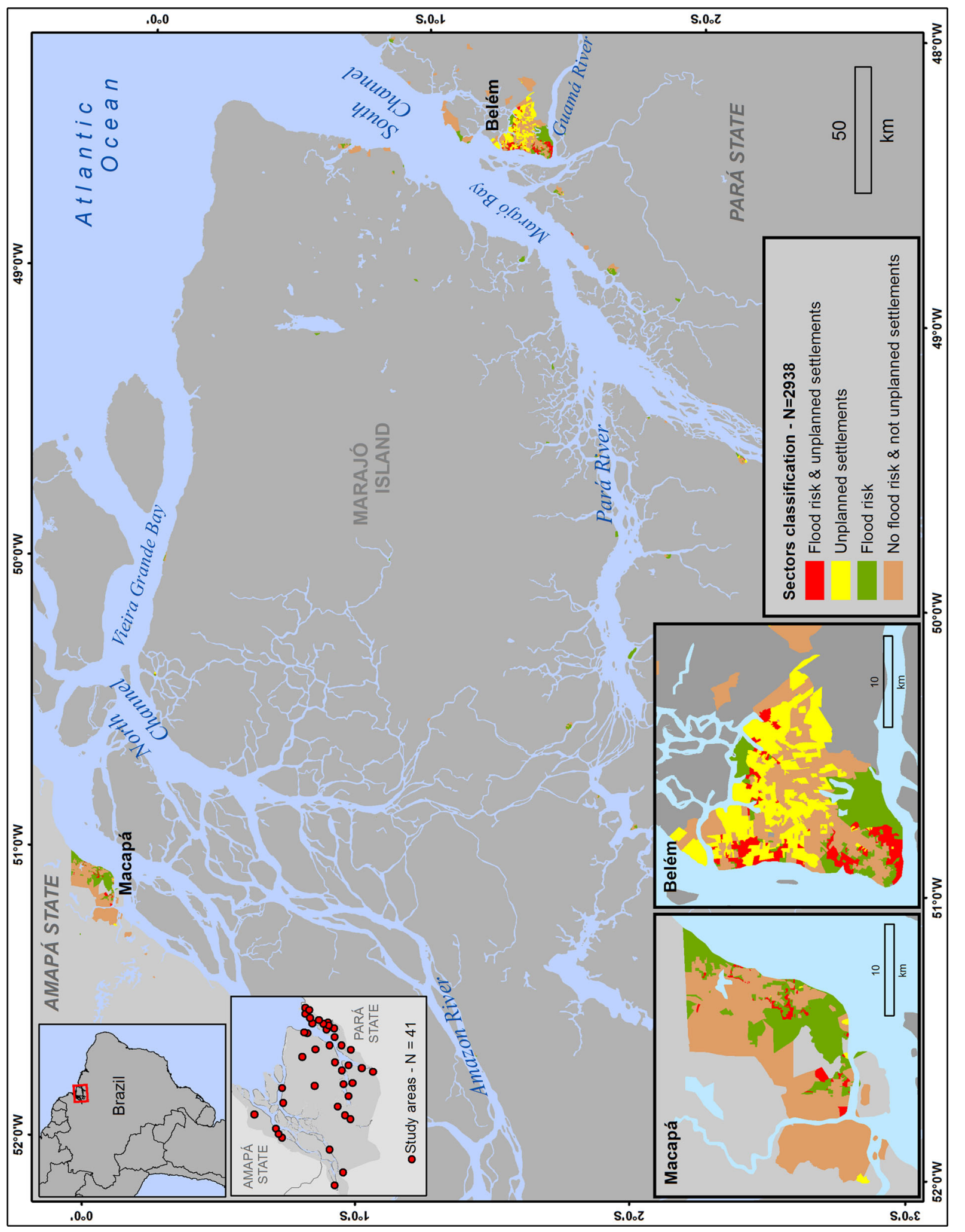

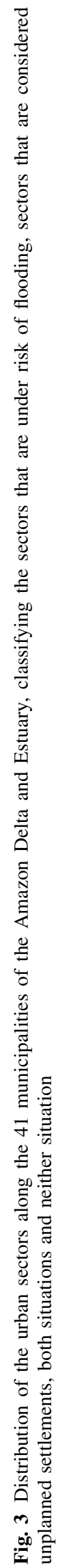


Fig. 4 Population size in 2010 divided in the three regions of the ADE: the small urban spaces (SUS), the Belém Metropolitan Region (BMR), and the Macapá Metropolitan Region (MMR), according to their sectors classification: flood risk areas and unplanned settlements; flood risk areas; unplanned settlements; no flood risk areas and not considered unplanned settlements

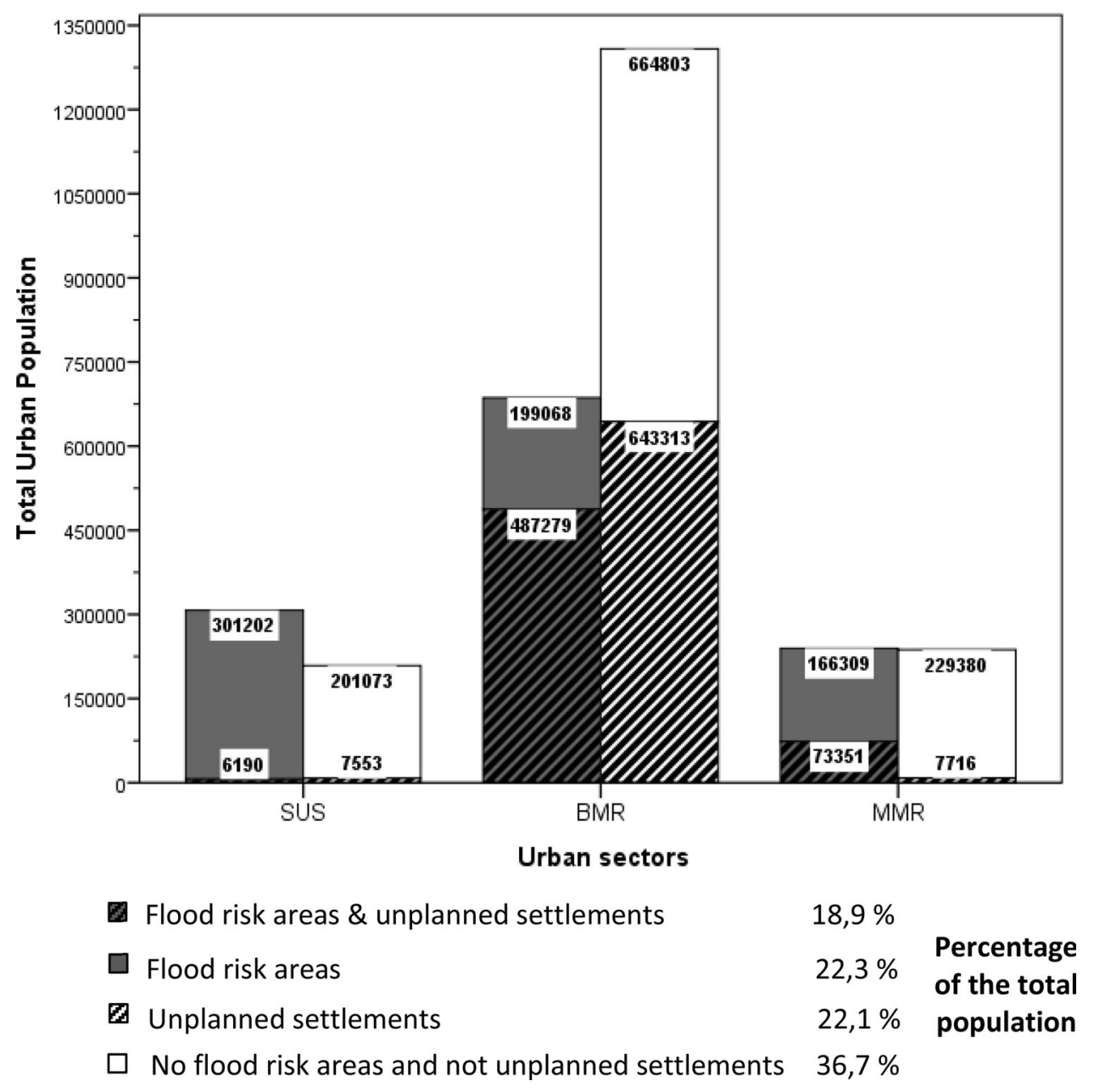

episodes are seasonal (Benatti 2011), characterized by a gradual rise of water that influences social life and organization in the urban ADE (Costa and Brondizio 2011; Vogt et al. 2016). There is no significant loss of life because of this gradual rise in water level and only eight deaths due to flood episodes were reported between 1991 and 2012 in the urban ADE (CEPED UFSC 2012).

Nevertheless, 30 events of severe floods and 20 events of flash floods in the urban ADE between 1991 and 2012 were declared as public disasters. These resulted in the displacement of thousands of people as well as affecting infrastructure (CEPED UFSC 2012). The magnitude of extreme flood impacts can greatly affect other aspects of these urban areas. Floods can affect people directly (e.g., through injuries) as well as indirectly (e.g., through displacement, the destruction of homes, spread of waterborne diseases, water shortages, disruption of essential services, impact on resources and financial loss), (EEA 2015; CEPED UFSC 2012).

Poorer households tend to live in riskier areas of the urban settlements (Adger 2006; Newton et al. 2012). Urban spaces in the ADE have little or poor planning due to:
1. high rates of urbanization (Costa and Brondizio 2011);

2. increased migration from rural to urban centers (Costa and Brondizio 2011; IBGE 2011);

3. occupation of marginal and lowlands areas, and (Benatti 2011);

4. land invasion and unclear property titles (Benatti 2011; IBGE 2011).

These factors contribute to increase the exposure of people to risk from flooding, disease and other chronic stresses (Adger 2006). Living in unplanned, often overcrowded settlements, increases the exposure of inhabitants to other risks, including pathogens, insect vectors, indoor pollution, violence, drug abuse and other social problems (WHO 2003).

Most of the unplanned settlements in the ADE are densely packed spatially and the housing units are crowded (IBGE 2010). They are often built of flimsy materials or on stilts, above the rivers. Stilt houses compose $83 \%$ of housing units in unplanned settlements of the MMR (IBGE 2011). Residents in the unplanned settlements of BMR represent about $10 \%$ of the total for Brazil, ranked the 
Table 2 Descriptive statistics for individual indicators divided according to the three regions of the Amazon Delta and Estuary: Belém Metropolitan Region (BMR), Macapá Metropolitan Region (MMR) and Small urban spaces (SUS)

\begin{tabular}{|c|c|c|c|c|c|c|c|c|c|}
\hline \multirow{2}{*}{$\begin{array}{l}\text { Indicator } \\
\text { (Percentage of households) }\end{array}$} & \multicolumn{3}{|l|}{ BMR } & \multicolumn{3}{|l|}{ MMR } & \multicolumn{3}{|l|}{ SUS } \\
\hline & Range & Mean & $\begin{array}{l}\text { Std. } \\
\text { deviation }\end{array}$ & Range & Mean & $\begin{array}{l}\text { Std. } \\
\text { deviation }\end{array}$ & Range & Mean & $\begin{array}{l}\text { Std. } \\
\text { deviation }\end{array}$ \\
\hline Water supply & 100.00 & 64.52 & 35.81 & 100.00 & 61.69 & 35.80 & 100.00 & 61.78 & 34.11 \\
\hline Domestic effluent collection & 100.00 & 29.77 & 31.31 & 100.00 & 8.88 & 20.56 & 88.20 & 2.92 & 8.43 \\
\hline Solid waste collection & 100.00 & 96.75 & 10.71 & 100.00 & 97.31 & 10.16 & 100.00 & 86.29 & 22.91 \\
\hline Open-air waste water & 100.00 & 45.33 & 40.17 & 100.00 & 43.00 & 41.07 & 100.00 & 34.69 & 36.50 \\
\hline Without drainage system & 100.00 & 51.18 & 38.93 & 100.00 & 65.18 & 40.76 & 100.00 & 87.53 & 22.63 \\
\hline Accumulation of solid waste & 100.00 & 9.31 & 20.79 & 100.00 & 14.95 & 27.21 & 100.00 & 7.82 & 18.85 \\
\hline $\begin{array}{l}\text { Children }(<10 \text { years ols) and elderly } \\
\text { ( }>65 \text { years old) }\end{array}$ & 41.04 & 24.25 & 3.10 & 36.65 & 27.78 & 4.79 & 25.63 & 30.20 & 4.33 \\
\hline $\begin{array}{l}\text { No income and income less than one } \\
\text { minimum wage }\end{array}$ & 97.79 & 66.28 & 23.43 & 100.00 & 64.67 & 21.25 & 67.37 & 85.08 & 10.91 \\
\hline Income between one and five minimum wage & 90.00 & 28.95 & 16.75 & 70.98 & 30.99 & 16.49 & 50.81 & 14.13 & 9.78 \\
\hline Income higher than five minimum wage & 57.89 & 4.86 & 9.86 & 78.57 & 4.59 & 6.73 & 13.71 & 0.97 & 1.60 \\
\hline
\end{tabular}

third by size after Rio de Janeiro and São Paulo. Moreover, our results indicate that $56.6 \%$ of the residents of BMR live in unplanned settlements. This proportion is the largest among all metropolitan areas in Brazil (IBGE 2011).

\section{Assessment of individual indicators}

The descriptive statistics and overview of the results are shown in Table 2 . The results indicate a huge variability in the indicators for the three region of the urban ADE elucidated by the large standard deviation for these indicators.

\section{Socio-economic dimension}

Figure 5 shows the percentage of households with a total monthly income of: (1) no income and income less than one minimum wage, (2) between one and five minimum wage, (3) more than five minimum wage. Results indicated a very low percentage of households (a mean of less than $5 \%$ in all regions) receives more than the minimum income that is considered necessary to supply the basic needs of the individual and family (DIEESE 2015). A mean of about $65 \%$ of the households receives less than one minimum wage in urban sectors of MMR and BMR, while in urban sectors of SUS this mean reaches $85 \%$ of the households, placing the ADE region among the poorest urban areas in Brazil (IBGE 2010). This situation results in a high dependency of families on federal subsidy programs, such as the Bolsa Familia (Costa and Brondizio 2011; Brondizio et al. 2013).

The cities in the ADE lack an adequate fiscal framework and administrative capacity to collect taxes (Brondizio 2011). This results in a high dependency on federal subsidies for investment in urban infrastructure (Brondizio et al. 2013). This insecurity and the lack of economic wellbeing, represented by the high number of poor households, contribute to the vulnerability of people and assets along the urban spaces of the ADE.

Figure 5 also shows that urban sectors of the ADE have similar proportions of children and the elderly population, indicating a minor proportion of population with limited physical capacity to deal with the impacts of hazards (Nobre et al. 2010).

\section{Infrastructure dimension}

Figure 6 shows the infrastructure patterns for the urban sectors along the ADE. Solid waste collection is provided to $100 \%$ of households in most sectors of the metropolitan regions and around $97 \%$ at SUS. However, a significant number of sectors lack a waste collection service and most municipalities lack appropriate landfills and treatment facilities. Solid waste accumulates in streets and is often dumped into watercourses, which clogs natural water flow and contributes to the flooding in the urban spaces of the ADE (Hardoy and Pandiella 2009; Costa and Brondizio 2011). Waste dumping on streets creates spaces for disease sprawl, insects, rodents and drug consumption. This situation also contributes to increased pollution of the land and water systems.

Domestic waste water collection is still very limited with less than $20 \%$ of households connected to this service in the metropolitan regions and almost totally absent in sectors located in the SUS (see Fig. 6). Due to this deficit, domestic effluents are disposed of in urban streams and rivers, affecting water quality. 
Fig. 5 Box plots representing individual socio-economic indicators, according to their region in the Amazon Delta and Estuary: Belém Metropolitan Region (BMR), Macapá Metropolitan Region (MMR) and Small urban spaces (SUS)
Region: SUS
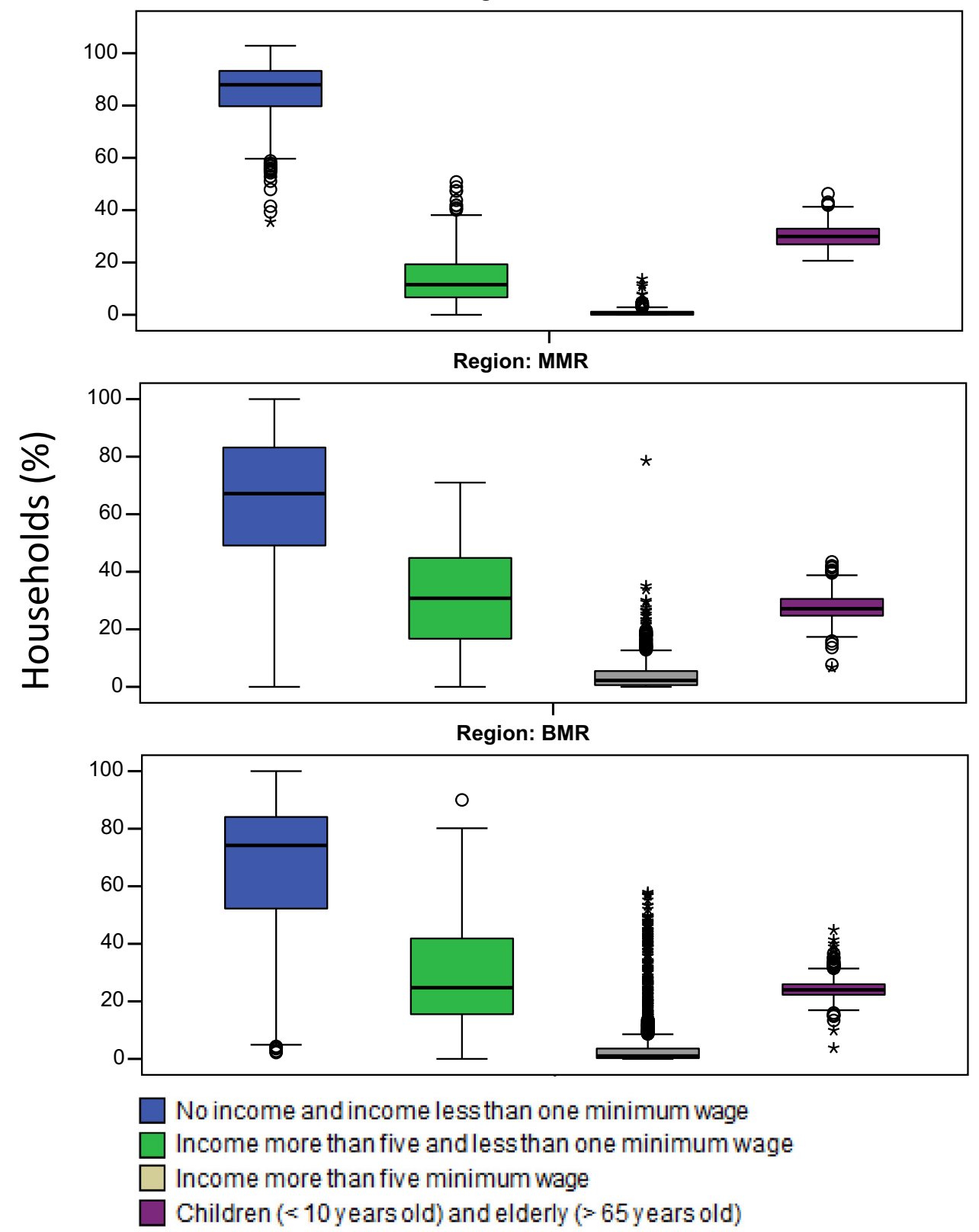

There is a variation in the public water supply service within all sectors. Although $80 \%$ of households are connected to public water supply, there are still households with no, or minimal, access to this service (see Fig. 6). These households mainly depend on water collection from the river, rain-harvesting or collective tap water, where the water is provided for the neighborhood as a whole. Residents that extract drinking water from unsafe water sources, such as directly pumping from rivers, are constantly exposing themselves to potential health risks (Hardoy and Pandiella 2009).

In terms of housing conditions, the percentage of households without a drainage system is very large. In the
SUS, almost $100 \%$ of the houses have no drainage system (see Fig. 6). The drainage system is limited in households of the two metropolitan regions in the ADE. Lack of drainage systems increases the risk of floods while the accumulation of uncollected wastes blocks drains and surface runoff (Hardoy and Pandiella 2009).

Despite the comprehensiveness of solid waste collection service within the urban ADE, there is still a large variability of households with accumulation of solid waste. The mean percentage of households with incidence of open-air waste water reaches near $50 \%$ in BMR and MMR and $34 \%$ at SUS, reflecting the 
Fig. 6 Box plots representing individual infrastructure indicators, according to their region in the Amazon Delta and Estuary: Belém Metropolitan Region (BMR), Macapá Metropolitan Region (MMR) and Small urban spaces (SUS)

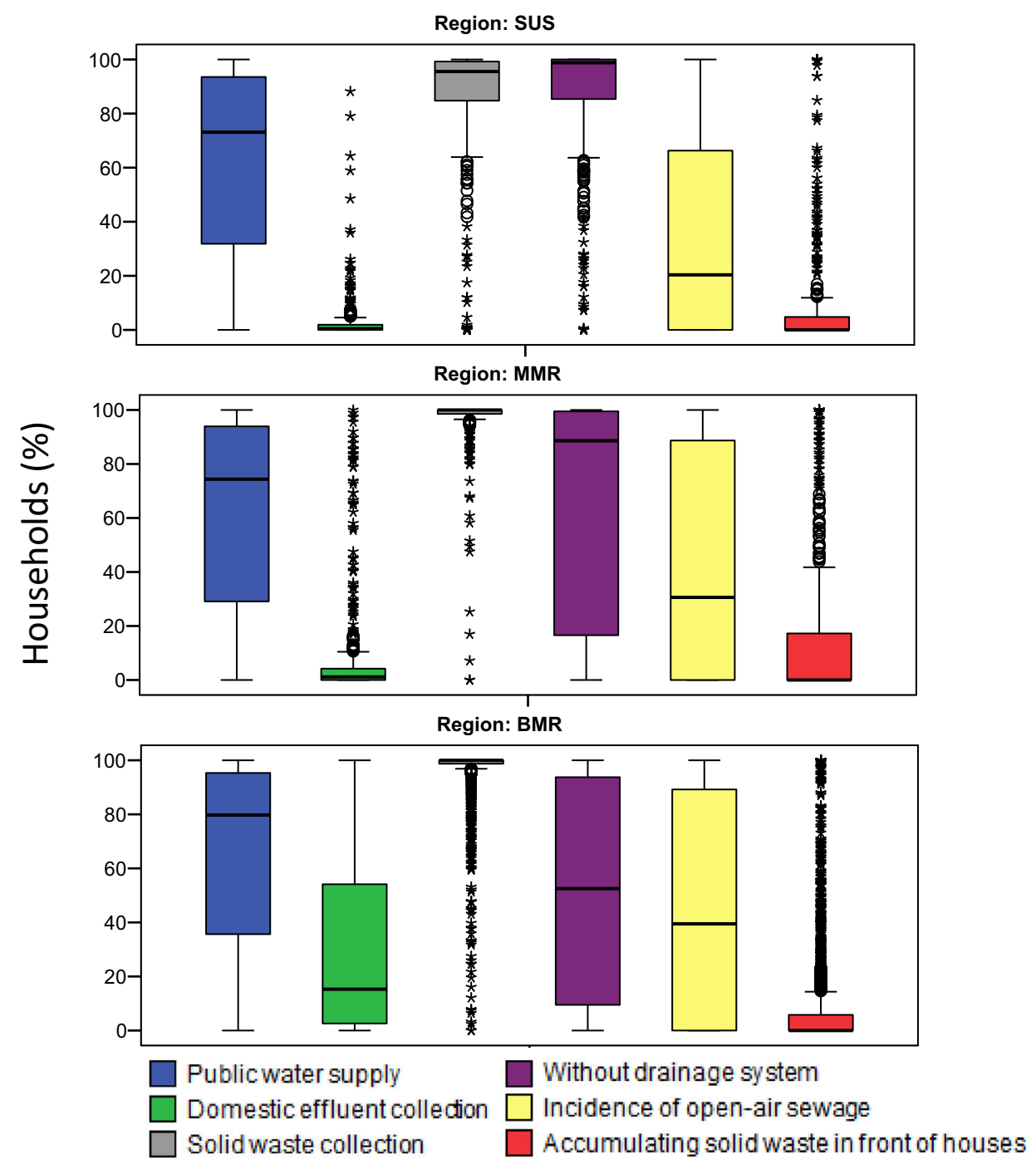

undesirable consequence of the poor housing conditions along the ADE (see Fig. 6).

Results indicate the deficiency of urban infrastructure along the ADE, especially in the small urban spaces. Lack of public services and infrastructure such as drinking water, sewage, proper waste collection and disposal, increases the health risks of population, posing additional challenges to advancing social and economic progress (IPS Amazônia 2014). Flood impacts can exacerbate these risks, since rising water levels can expose people by direct contact with contaminated water after a disaster (CEPED UFSC 2012). Health risks are related to waterborne diseases, including: leptospirosis, cholera, hepatitis, amoebic dysentery, typhoid fever, diarrhea caused by Escherichia coli, and vector-borne diseases that are related to water, such as yellow fever, malaria, dengue and zika virus.

The findings of this study corroborate those of Costa and Brondizio (2011), who analyzed data from IBGE 2000 and found no significant difference between cities built at different historical periods and available public services and infrastructure. Our study found no recent relevant improvements with respect to the services and infrastructure of urban spaces of the ADE. Exceptions exist to some urban infrastructure not assessed in our index, such as electricity service, which has improved when compared to census data 2000 presented in Costa and Brondizio (2009, 2011). Today, nearly $100 \%$ of the households in almost all urban sectors of the ADE are served by electricity (IBGE 2010), possibly due to investments made during the Federal Government Program called Luz Para Todos ("Light for All").

Some other investments in sanitation and infrastructure on unplanned settlements along the ADE were made since 2007 when the federal government initiated a Program of Accelerated Growth (PAC) dedicated to urban infrastructure (BRASIL 2015). Yet, according to Avelar et al. (2013), only $10 \%$ of the population of the Belem 
Metropolitan Region (BMR) living in unplanned settlements have benefited from the incentives of the PAC. The integrated system for waste water treatment for BMR was planned but not implemented (Avelar et al. 2013).

\section{Relationship between indicators}

A correlation matrix was generated (see supplementary material) to explore the relationships between household income, sensitive age groups, sanitation services and housing conditions. Some of the major findings of the correlation analysis yielded the following

1. Income is positively correlated with access to drainage, and negatively with effluent collection and solid waste collection. Households with income below less than minimum wage or with no income had the lowest level of access to these services. Households with income between one and five minimum wage have significant more access to domestic effluent collection and solid waste collection;

2. Households income below one minimum wage and no income tend to have a higher proportion of sensitive population (children and elders). This may be attributed to limited sources of income for these two major age groups as children are generally economically inactive population and elderly may represent a source of income through retirement pension.

3. There is no significant correlation between sanitation services (water supply, effluent collection and solid waste collection) and housing conditions (accumulation of solid waste and open-air sewage. Although solid waste collection is very representative in across urban sectors, solid waste is also dumped in street corners, river borders or drainage channels and river ways. Very often sewer pipes are clogged, so waste water is drained in the open air even in sectors served with sewage collection.

\section{Assessment of the vulnerability index}

Figure 7 shows the overall vulnerability for the urban sectors of the ADE. Results indicated that about $3.37 \%$ of the urban ADE area presented a low degree of vulnerability, against $34.72 \%$ with moderate degree, $60.30 \%$ with high degree and $2.60 \%$ with very high degree of vulnerability. While populations are more concentrated in areas with moderate degree of vulnerability in all regions, about $34 \%$ of these populations are located in areas with high to very high degree of vulnerability, reaching over 1 million inhabitants.

Our results indicate that vulnerability of ADE cities increases from the city center to the recent peri-urban expansion (see Fig. 7), corroborating with results found by Perz (2000) which pointed out that the urban population growth during the 1980s have led to an intra-regional difference within the city in terms of environmental quality. He indicated that old established urban areas showed higher environmental quality, suggesting a deterioration which occurred in part due to the establishment of newly formed occupations. His study detected that households in new urban areas have considerably less resources and services, such as waste collection and water supply and are more exposed to environmental hazards than the older urban areas, a trend still observed in this study.

A correlation analysis was performed between an independent variable which in our case was the average household income within each sector and the overall vulnerability. While looking at percentage households in different income categories allows us to assess vulnerabilities within sectors, the average household income looks at income and vulnerability relationships between different sectors. The Spearman's correlation value of $r=-0.533$ with a $p$ value $<0.01$ suggests an inverse correlation between the average household income and the vulnerability of urban sectors. Thus, the higher the average income of the households, the lower the vulnerability within the urban sectors of the ADE. This suggests that poorer urban spaces present higher degrees of vulnerability.

The degree of vulnerability of the urban ADE will define the impacts of extreme events on society and urban systems. Poor planning and rapid urbanization result in high density, high concentration of poverty, and higher levels of exposure to environmental hazards. Coupled with inadequate investments in infrastructure and public services, the increasing exposure of urban settlements and inhabitants to flood hazards will escalate the severity of potential impacts due to future climate change (IPCC 2014).

Hence, to cope with the accelerated urbanization of the ADE (Brondizio 2013), Costa and Brondizio (2009, 2011) argue that municipalities of the ADE should seek ways to diversify their source of income and decrease their dependency on federal government subsidies. While most municipalities in the ADE have strong and active resource economies (agroforestry, fishing, mining, agriculture, and ranching), industries aggregating value and taxation to these resources are virtually inexistent.

The vulnerability assessment presented in this study shows the distinct roles for socio-economic sensitivity, infrastructural vulnerability, and flood exposure. These are dependent not just on the available resources and services in this region but also on the adaptive capacity of the population living in these areas to make use of existing services. This reiterates the importance of considering different dimensions of vulnerability as outlined in our conceptual model 


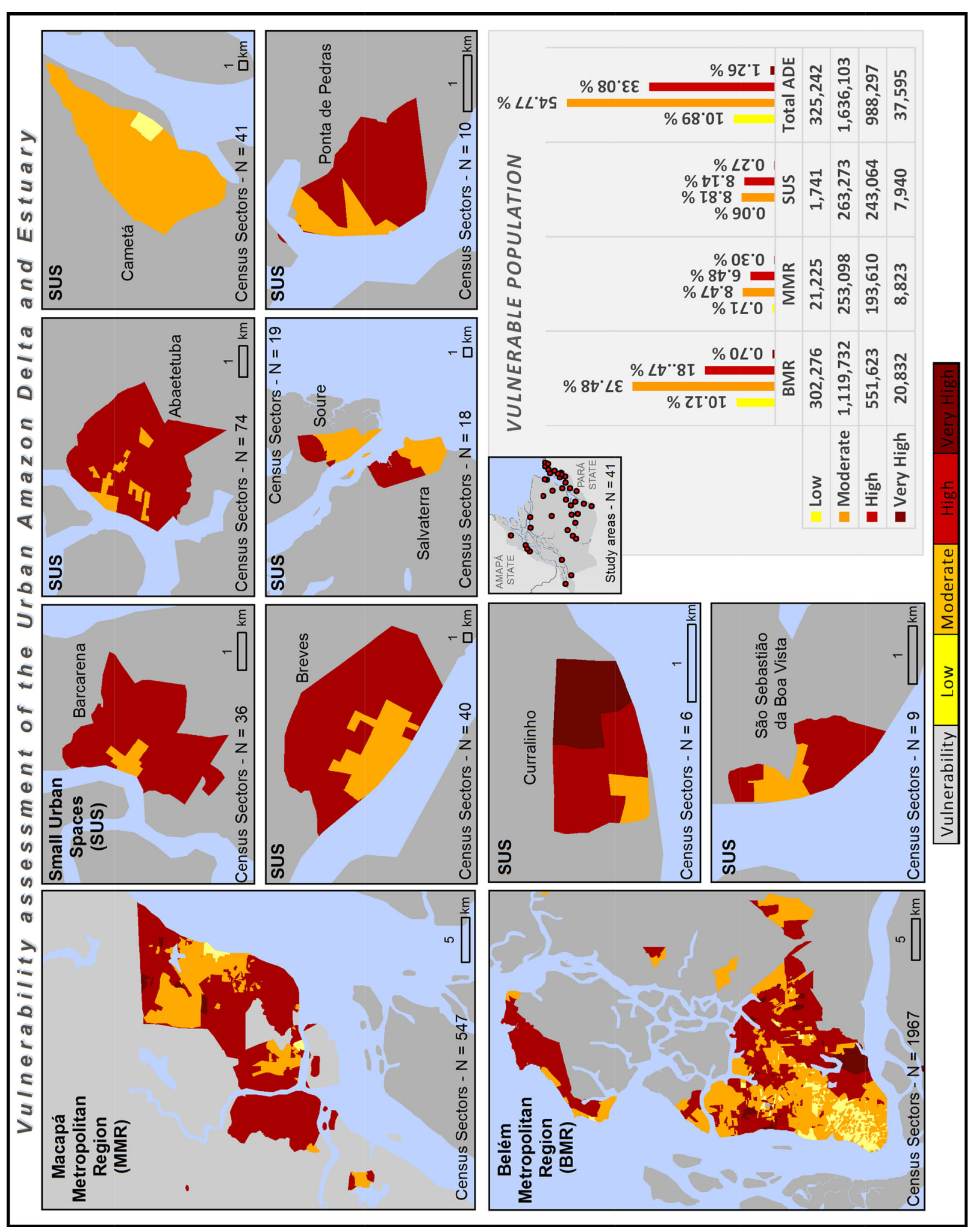

हี

प๐

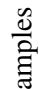

$\stackrel{0}{2}$

空

金

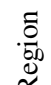

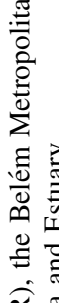

金芯

$\sum^{\circ}$ ㅇ

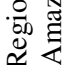

च

훙

$\sum^{0}$

葏

芩范

焉

.$\Xi$ त्त्र

害

䨌

导

4

$Ð \stackrel{0}{\Xi}$

50 0

를

○

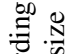

ठ․․

흘

远

प्ठ

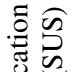

: 
and how their relationships affect and are affected by crossscale processes. In other words, the analysis presented here shows the importance of understanding relationships between vulnerability processes and patterns at different levels of aggregation. Analyzing interactions among social, physical, and ecological conditions at finer units of analysis allow one to gage the role of social and economic inequalities on levels of vulnerability otherwise not observable at the scale of whole urban areas or municipalities.

\section{Methodological discussions and implications}

Using a larger scale such as a city-level analysis and aggregating the data from the sector level reduces the visibility of heterogeneity present within these datasets. On the other hand, though the higher resolution of the sector level data does provide for greater accuracy in terms of assessment by separating the variability present in terms of socio-economic and environmental characteristics, these data sets often have limited base of information (Richards and VanWey 2015). This explains the limitations in terms of choice of scale and variables used for the vulnerability analysis and also explains the subjectivity involved in making this choice. Future work will involve perceived vulnerability using in situ semi-structured interviews to better assess socio-economic sensitivity and adaptive capacity of individual households within the sectors.

Lack of higher resolution topographic data at the sector level limited our flood risk analysis in the urban sectors of the ADE. Other studies used similar methodologies to characterize inundation areas in this region, these include Valeriano and Rosseti (2008) and Sadeck et al. (2012), and in other regions, including Kebede and Nicholls (2011) and Fluet-Chouinard et al. (2015). However, the use of the SRTM dataset to characterize elevation raises the question of data accuracy, as SRTM measurements can be influenced by vegetation in areas that have been substantially altered by human actions, such as built-up urban areas. Nevertheless, despite these limitations, the analysis provides important results as a first attempt to better understand urban flooding along the ADE. For a more robust assessment of flood exposure and risk, future analysis will require local specific environmental monitoring, such as long-term measurements of tides and finer resolution of topographic data.

Finally, this study offers a holistic view of the interaction of multiple factors affecting the vulnerability of the ADE. The results can provide a knowledge base for decision makers and managers to prioritize and develop sustainable management efforts to enhance resilience in the urban ADE (e.g., improvement of sanitation conditions, adaptive capacity). The authors focus on the need for the transition of these management goals to move from a theoretical discourse to practice and implementation for this approach to be truly holistic (Szabo et al. 2015).

\section{Conclusions}

This paper builds upon previous concepts and analysis of vulnerability to propose a conceptual model and application to the urban areas of the Amazon Delta and Estuary. Urban vulnerability in the ADE is conceptualized as a function of three interconnected dimensions: the exposure of population and urban ecosystems to flood hazard, and both the socio-economic sensitivity and the urban infrastructure, which in turns determines the adequate capacity for household adaptation and resilience within the urban spaces. Our conceptual model also highlights the roles that ecosystem services play in modulating both the event and the social systems that create conditions of vulnerability in the urban ADE.

A multi-layer pair wise hierarchical model has been explored using the analytical hierarchical process, which helps to gage level of interdependence and the role of different dimensions of vulnerability. The correlation analysis between the indicators allows for creating a firsthand understanding of connected variables and subsets within these indicators allowing for assessing the long term dependencies, which may not be readily apparent. Further insight into longitudinal data for such sites will allow for establishing a more robust vulnerability assessment and evaluation model.

This is the first study to examine vulnerability in the ADE at both within and between urban areas. Our geospatially explicit approach allows the identification of hotspots of urban vulnerability in the ADE, where $60 \%$ of its urban areas present high degree of vulnerability and $60-90 \%$ of the urban population live in conditions of moderate to high degree of vulnerability. Cities present patterns in which vulnerability increases from city centers to newly peri-urban spaces.

An analysis of the study results provides answers to our original research questions.

1. How many people are under risk of flooding in the urban $A D E$ ? Over 1.2 million people are under risk of flooding in the ADE. Inhabitants of $41 \%$ of urban sectors along the ADE are at risk. Our results indicate that the urban spaces of the ADE are exposed to potential risks as a result of combined poor urban conditions and high flood hazard. Overall, the urban sectors have poor infrastructure and services and the residents have low household incomes.

2. How many people live in unplanned settlements and are under risk of flooding in these urban areas? Over 
half million people are living in unplanned settlements under risk of flooding, representing $19 \%$ of the total urban population in the ADE. The unplanned settlements represent about $40 \%$ of the sectors, with an urban population reaching over 1.2 million people, mainly in the BMR.

3. Which factors exacerbates the existing vulnerabilities in the urban $A D E$ ?

(1) Poor urban infrastructure and public services (safe drinking water, domestic effluent collection, appropriate solid waste disposal and suitable drainage system);

(2) Low income of urban dwellers

(3) Dense occupation of flood-prone areas

(4) Accelerated urbanization and poor governances.

The analytical model employed in the analysis (AHP) allowed us to gage the role of different dimensions and factors affecting vulnerability. The derived priorities established Infrastructure with an overall weight of 0.7 compared to 0.2 for socio-economic sensitivity and 0.1 for flood exposure based variables. This implies that investment in constructing and maintaining public infrastructure for drainage and sanitation will impact the largest number of people in the region, independent of income.

The urban spaces of the ADE are critically deficient in public sanitation and housing conditions, such as water provision, domestic effluent collection and drainage systems, especially in some remote areas. Population lives over open air sewage while struggle with large floods from overflows of river channels contaminated by sewage. The sum of these factors increases the vulnerability along the urban spaces of the ADE, exposing the population to frequent risks of physical displacement and chronic health risks. The rapid urbanization, poor life conditions, inadequate or absent investments in infrastructure and public services all influence the severity of the population in the ADE and increasingly the ability of the population to confront a changing climate and more frequent extreme weather events. In future work, we plan to add more variables to the analytical multi-dimensional model presented in the paper, including field derived datasets developed in collaboration with residents living in different parts of the region.

Acknowledgments We would like to thank the anonymous reviewers for their constructive and helpful suggestions. We acknowledge the Belmont Forum funding program (Coastal Vulnerability Theme G8HORC) and the National and State Science Foundations supporting the project "Catalyzing action towards sustainability of deltaic systems with an integrated modeling framework for risk assessment", in particular the NSF in the United States of America (Grant \#1342898). Andressa V. Mansur acknowledges the Erasmus Mundus programme: EMJD Marine and Coastal Management for their support. We also acknowledge the "Sociocultural adaptations of Caboclos to extreme tidal events in the Amazon estuary" sponsored by the International Development Research Centre (IDRC) of Canada for the financial supporting for the Workshop in Belém, May 2015 and the colleagues of the workshop organization, in particular Zita Sebesvari and Oriana Almeida. Finally, we acknowledge the support of the Center for the Analysis of SocialEcological Landscapes (CASEL) at Indiana University, where this research was developed and members of the "Frente dos Moradores Prejudicados da Bacia do Una" [an organization of harmed residents in the Una River watershed] for their friendly support during the field work in Belém.

\section{References}

Adger WN (2006) Vulnerability. Glob Environ Change 16:268-281. doi:10.1016/j.gloenvcha.2006.02.006

Avelar WM, Souza ES, Pont JPX, Melo ACC (2013) O Programa de aceleração do crescimento (PAC) e a urbanização de favelas na região metropolitana de Belém-PA. Anais: Encontros Nacionais da ANPUR, p 15

Barbieri AF, Monte-Mór RL, Bilsborrow RE (2009) Towns in the jungle: exploring linkages between rural-urban mobility, urbanization and development in the Amazon. In: de Sherbiniin A, Rahman A, Barbieri A, Fotso JC, Zhu Y (eds) Urban populationenvironment dynamics in the developing world: case studies and lessons learned. Committee for international cooperation in national research in demography (CICRED), Paris, p 316. http:// www.populationenvironmentresearch.org/workshops.jsp\#W2007

Benatti JH (2011) Proposals, experiences, and advances in the legalization of land tenure in the Várzea. In: Pinedo-Vasquez M, Ruffino ML, Padoch C, Brondízio ES (eds) The Amazon Várzea: the decade past and the decade ahead. Springer and The New York Botanical Garden, New York

BRASIL, República Federativa; Governo Federal (2015) Sobre o PAC (em linha). Brasília, Governo Federal. http://www.pac.gov. br/sobre-o-pac. Accessed 1 July 2015

Brondizio ES, Vogt N, Hetrick SS, Costa S, Anthony EJ, Mansur AV (this issue) A conceptual framework for analyzing deltas as coupled social ecological systems: an example from the Amazon River Delta and Estuary. Sustain Sci (Special Issue: Sustainable Deltas: Livelihoods, Ecosystem Services, and Policy Implications)

Brondizio ES (2011) Forest resources, family networks and the municipal disconnect: examining recurrent underdevelopment in the Amazon Estuary. In: Pinedo-Vasquez M, Ruffino M, Padoch C, Brondizio ES (eds) The Amazonian Várzea: the decade past and the decade ahead. Springer Publishers co-publication with The New York Botanical Garden Press, Dordrecht, pp 207-232

Brondizio ES (2013) A microcosm of the Anthropocene: socioecological complexity and social theory in the Amazon. Perspectives: Journal de la Reseaux Francaise d'Institut d'études avancées (RFIEA) 10:10-13 [Autumn 2013]

Brondizio ES, Vogt N, Siqueira A (2013) Forest resources, city services: globalization, household networks, and urbanization in the Amazon estuary. In: Morrison K, Hetch S, Padoch C (eds) The social life of forests. The University of Chicago Press, Chicago, pp 348-361

Browder JD, Godfrey BJ (1997) Rainforest cities: urbanization, development and globalization of the Brazilian Amazon. Columbia University Press, New York

CEPED UFSC (Centro Universitário de Estudos e Pesquisas sobre Desastres-Universidade Federal de Santa Catarina) (2012) Atlas Brasileiro de Desastres Naturais 1991 a 2010. Volume Brasil, Volume Pará, Volume Amapá, Florianópolis 
Chambers R (1989) Vulnerability, coping and policy (editorial introduction). IDS Bull 2(2):1-7

Cohen MCL, Lara RJ (2003) Temporal changes of mangrove vegetation boundaries in Amazonia: application of GIS and remote sensing techniques. Wetl Ecol Manage 11:223-231

Cohen MCL, Lara RJ, Ramos JFF, Dittmar T (1999) Factors influencing the variability of magnesium, calcium and potassium in waters of a mangrove creek in Bragança, North Brazil. Mang Salt Marsh 3:9-15

Cohen MCL, Lara RJ, Smith CB, Angélica RS, Dias BS, Pequeno T (2008) Wetland dynamics of Marajó Island, northern Brazil, during the last 1000 years. Catena 76:70-77

Costa S, Brondizio ES (2009) Dependência Inter-urbana entre as Cidades Amazônicas: Crescimento Urbano, Deficiências em Infra-estrutura e Redes Sociais. REDES, vol 14, pp 211-234. http://unuhospedagem.com.br/revista/rbeur/index.php/anais/arti cle/viewFile/4162/4048

Costa S, Brondizio ES (2011) Cities along the floodplain of the Brazilian Amazon: characteristics and trends. In: PinedoVasquez M, Ruffino ML, Padoch C, Brondízio ES (eds) The Amazon Várzea: the decade past and the decade ahead. Springer and The New York Botanical Garden, New York

Costa S, Rangel JA, Montoia G, Lima VM, Issa P (2011) Pequenas cidades do estuário do rio Amazonas: fluxo econômico, crescimento urbano e as novas velhas urbanidades em Ponta de Pedras, estado do Pará. XII SIMPURB-Ciência e Utopia. Associação Brasileira de Geografia, Belo Horizonte

Crossland CJ, Kremer HH, Lindeboom HJ, Marshall CJI, Le Tissier MDA (2005) Coastal fluxes in the anthropocene; the land-ocean interactions in the coastal zone project of the International Geosphere-Biosphere Programme. Springer, Berlin

Day JW, Martin JF, Cardoch L (1997) System functioning as a basis for sustainable management of deltaic ecosystems 25TH ANNIVERSARY INVITED PAPER system functioning as a basis for sustainable management of deltaic ecosystems. Environ Stud 25:115-153. doi:10.1080/08920759709362315

DIEESE (2015) Salário mínimo nominal e necessário. http://www. dieese.org.br/analisecestabasica/salarioMinimo.html\#2010. Accessed 12 Apr 2015

EEA European Environment Agency (2015) Adaptation to climate change. http://ec.europa.eu/clima/policies/adaptation/what/docu mentation_en.htm. [Accessed on 05/25/2015]. Accessed 25 May 2015

Eisma D, Boer de PL, Ridderinkhof H, Cadée GC, Philippart C, Dijkema K (1997) Intertidal deposits: river mouths, tidal flats, and coastal lagoons. Marine Science Series, pp 199-207

Ericson JP, Vörösmarty CJ, Dingman SL, Ward LG, Meybeck M (2006) Effective sea-level rise and deltas: causes of change and human dimension implications. Glob Planet Change 50:63-82. doi:10.1016/j.gloplacha.2005.07.004

Fearnside PM (1995) Potential impacts of climatic change on natural forests and forestry in Brazilian Amazonia. For Ecol Manage 78:51-70

Figueroa SN, Nobre CA (1990) Precipitation distribution over central and western tropical South America. Climanálise 5:36-45

Fluet-Chouinard E, Lehner B, Rebelo LM, Papa F, Hamilton S (2015) Development of a global inundation map at high spatial resolution from topographic downscaling of coarse-scale remote sensing data. Remote Sens Environ 158:348-361

Foufoula-Georgiou E et al (2013) A vision for a coordinated international effort on delta sustainability. In: Young G, Perillo GME (eds) Deltas: landforms, ecosystems and human activities. IAHS Publ, Wallingford, pp 3-11

França MC, Francisquini MI, Cohen MCL, Pessenda LCR, Rossetti DF, Guimarães JTF, Smith CB (2012) The last mangroves of Marajó Island-Eastern Amazon: impact of climate and/or relative sea-level changes. Rev Palaeobot Palynol 187:50-65. doi:10.1016/j.revpalbo.2012.08.007

Füssel HM (2007) Vulnerability: a generally applicable conceptual framework for climate change research. Glob Environ Change 17:155-167. doi:10.1016/j.gloenvcha.2006.05.002

GeoAmazonia (2009) Environment outlook for Amazonia, United Nations Environment Programme (UNEP), Amazon Cooperation Treaty Organization (ACTO) and Research Center of Universidad del Pacifico (CIUP), United Nations Development (UNDP). In: http://www.unep.org/pdf/GEOAMAZONIA.pdf

Guedes GR, Costa S, Brondizio ES (2009) Revisiting the hierarchy of urban areas in the Brazilian Amazon: a multilevel approach. Popul Environ 30:159-192

Guedes GR, Brondizio ES, Barbieri AF, Anne R, Penna-Firme R, DAntona A (2012) Poverty and inequality in the rural Brazilian Amazon: a multidimensional approach. Human Ecol 40:41-57

Guenni LB, Cardoso M, Goldammer J, Hurtt G, Mata LJ, Ebi K, House J, Valdes J (2005) Regulation of natural hazards: floods and fires. Ecosystems and human well-being: current state and trends: findings of the Condition and Trends Working Group of the Millennium Ecosystem Assessment 1, pp 441-453

Hardoy J, Pandiella G (2009) Urban poverty and vulnerability to climate change in Latin America. Environ Urban 21:203-224. doi: $10.1177 / 0956247809103019$

Hori S, Saito Y (2007) Classification, architecture and evolution of large-river deltas. In: Gupta A (ed) Large rivers: geomorphology and management. Wiley, Chichester, UK, pp 75-92. doi:10. 1002/9780470723722.ch6

IPS Amazônia 2014 (Índice de Progresso Social na Amazônia brasileira) (2014) In: Santos D, Celentano D, Garcia J, Aranibar A, Veríssimo A (eds) Social Progress Imperative, 2014. Imazon (tituto do Homem e Meio Ambiente da Amazônia), Belém

IBGE. Instituto Brasileiro de Geografia e Estatística (Brazilian Institute of Geography and Statistics) (2010) Data from demographic census 2010. Census online: http://www.ibge.gov.br

IBGE Instituto Brasileiro de Geografia e Estatística (Brazilian Institute of Geography and Statistics) (2011) Censo Demográfico 2010 Aglomerados subnormais: Informações territorias. Censo demogr. Rio de Janeiro, p 251. http://biblioteca.ibge.gov.br/ visualizacao/periodicos/552/cd_2010_agsn_if.pdf

IPCC (2014) Climate change 2014: impacts, adaptation, and vulnerability. Part A: global and sectoral aspects. In: Field CB, Barros VR, Dokken DJ, Mach KJ, Mastrandrea MD, Bilir TE, Chatterjee M, Ebi YO, Estrada RC, Genova B, Girma ES, Kissel AN, Levy S, MacCracken PR, Mastrandrea LL, White (eds) Contribution of working group II to the fifth assessment report of the intergovernmental panel on climate change. Cambridge University Press, Cambridge, United Kingdom and New York

Kasperson RE, Dow K, Archer E, Caceres D, Downing TE, Elmqvist T, Folke C, Han G, Iyengar K, Vogel C, Wilson K, Ziervogel G (2005) Vulnerable peoples and places, chapter 6 of the millennium ecosystem assessment: conditions and trends. Island Press, Washington, D.C., pp 143-164

Kebede AS, Nicholls RJ (2011) Exposure and vulnerability to climate extremes: population and asset exposure to coastal flooding in Dar es Salaam, Tanzania. Reg Environ Change 12:81-84. doi:10. 1007/s10113-011-0239-4

Laukkonen J, Blanco PK, Lenhart J, Keiner M, Cavric B, KinuthiaNjenga C (2009) Combining climate change adaptation and mitigation measures at the local level. Habitat Int 33:287-292. doi:10.1016/j.habitatint.2008.10.003

Luers AL (2005) The surface of vulnerability: an analytical framework for examining environmental change. Glob Environ Change 15(3):214-223 
Marengo JA, Liebmann B, Kouski VE, Filizola NP, Wainer IC (2001) Onset and end of the rainy season in the Brazilian Amazon basin. J Clim 14:833-852

McGranahan G, Marcotullio P, Bai X, Balk D, Braga T, Douglas I, Elmqvist T, Rees W, Satterthwaite D, Songsore J (2005) Urban systems. Ecosystems and Human Well-Being, Current State and Trends, Findings of the Condition and Trends Working Group. Millennium Ecosystem Assessment Series, vol 1

Newton A, Weichselgartner J (2014) Hotspots of coastal vulnerability: a DPSIR analysis to find societal pathways and responses. Estuar Coast Shelf Sci 140:123-133. doi:10.1016/j.ecss.2013.10.010

Newton A, Carruthers TJB, Icely J (2012) The coastal syndromes and hotspots on the coast. Estuar Coast Shelf Sci 96:39-47. doi:10. 1016/j.ecss.2011.07.012

Nobre C, Young AF, Saldiva P, Marengo JA, Nobre AD, Alves Jr S, Silva GCM, Lombardo M (2010) Vulnerabilidade das Megacidades Brasileiras às Mudanças Climáticas: Região Metropolitana de São Paulo. INPE: n. 32

Overeem I, Syvitski JPM (2009) Dynamics and vulnerability of delta systems. LOICZ Reports and Studies (35), GKSS Research Center, Geesthacht

Perz SG (2000) The quality of urban environments in the Brazilian Amazon. Soc Ind 49:181-212

Pinedo-Vasquez M, Ruffino ML, Padoch C, Brondízio ES (2011) The Amazon Várzea: the decade past and the decade ahead. Springer and The New York Botanical Garden, New York. doi:10.1007/ 978-94-007-0146-5

Revi ADE, Satterthwaite DE, Aragón-Durand F, Corfee-Morlot J, Kiunsi RBR, Pelling M, Roberts DC, Solecki W (2014). Urban areas. In: Field CB, Barros VR, Dokken DJ, Mach KJ, Mastrandrea MD, Bilir TE, Chatterjee M, Ebi M, Estrada YO, Genova RC, Girma B, Kissel ES, Levy AN, MacCracken S, Mastrandrea PR, White LL (eds) Climate change 2014: impacts, adaptation, and vulnerability. Part A: global and sectoral aspects. Contribution of Working Group II to the Fifth Assessment Report of the Intergovernmental Panel on Climate Change. Cambridge University Press, Cambridge, United Kingdom and New York, pp 535-612

Richards P, VanWey L (2015) Where deforestation leads to urbanization: how resource extraction is leading to urban growth in the Brazilian Amazon. Ann Assoc Am Geogr 105:806-823

Saaty TL (1980) The analytical hierarchy process. McGraw-Hill, New York

Saaty TL (2008) Decision making with the analytic hierarchy process. Int J Serv Sci 1:83-98

Sadeck LWR, Souza AAA, Silva LCT (2012) Mapeamento das Zonas de Risco às Inundações no Município de Belém-PA. VI Encontro Nacional de Anppas, Belém, PA

Silva HP (2011) Life is hard, life is beautiful: some perspectives on health and aging in Amazonian rural populations. In: PinedoVasquez M, Ruffino ML, Padoch C, Brondízio ES (eds) The Amazon Várzea: the decade past and the decade ahead. Springer and The New York Botanical Garden, New York

Su S, Pi J, Wan C, Li H, Xiao R, Li B (2015) Categorizing social vulnerability patterns in Chinese coastal cities. Ocean Coast Manag 116:1-8

Syvitski JPM (2008) Deltas at risk. Sustain Sci 3:23-32. doi:10.1007/ s11625-008-0043-3

Syvitski JPM, Kettner AJ, Overeem I, Hutton EWH, Hannon MT, Brakenridge GR, Day J, Vörösmart C, Saito Y, Giosan L, Nicholls RJ (2009) Sinking deltas due to human activities. Nat Geosci 2:681-686. doi:10.1038/ngeo629
Szabo S, Renaud FG, Hossain MdS, Sebesvári Z, Matthews Z, Foufoula-Georgiou E, Nicholls RJ (2015) Sustainable development goals offer new opportunities for tropical delta regions. Environ Sci Policy Sustain Develop 57:16-23. doi:10.1080/ 00139157.2015.1048142

Takiyama LR, Silva URL, Jimenez EA, Pereira RA, Zacardi DM, Fernandes EF, Souto FAF, Silva LMA, Silva MS, Santos MAC, Neto SVC, Santos VF (2012) Projeto Zoneamento Ecológico Econômico Urbano das Áreas de Ressacas de Macapá e Santana, Estado do Amapá Relatório Técnico Final

Tapsell S, McCarthy S, Faulkner H, Alexander M (2010) Social vulnerability and natural hazards. CapHaz-Net WP4 Report, Flood Hazard Research Centre, FHRC, Middlesex University, London. http://caphaz-net.org/outcomes-results/CapHazNet_ WP4_Social-Vulnerability.pdf

Tejedor A, Longjas A, Zaliapin I, Foufoula-Georgiou E (2015a) Delta channel networks: 1. A graphtheoretic approach for studying connectivity and steady-state transport on deltaic surfaces. Water Resour Res. doi:10.1002/2014WR016577

Tejedor A, Longjas A, Zaliapin I, Foufoula-Georgiou E (2015b) "Delta channel networks: 2. Metrics of topologic and dynamic complexity for delta comparison, physical inference and vulnerability assessment. Water Resour Res. doi:10.1002/2014WR 016604

Tessler ZD, Vörösmarty CJ, Grossberg M, Gladkova I, Aizenman H, Syvitski JPM, Foufoula-Georgiou E (2015) Profiling risk and sustainability in coastal deltas of the world. Science 349:638-643

Turner BL, Kasperson RE, Matson P, McCarthy JJ, Corell RW, Christensen L, Eckley N, Kasperson JX, Luers A, Martello ML, Polski C, Pulsipher A, Schiller A (2003) A framework for vulnerability analysis in sustainability science. Proc Natl Acad Sci USA 100(14):8074-8079. doi:10.1073/pnas.1231335100

Valeriano MM, Rosseti DF (2008) Topographic modeling of Marajó Island with SRTM data. Revista Brasileira de Geomorfologia 9:53-64. doi:10.1016/j.apgeog.2011.05.004

Van der Most H, Marchand M, Bucx T, Nauta T, Van Staveren M (2009) Towards sustainable development of deltas, estuaries and coastal zones. Description of eight selected deltas. Deltares, Delft, The Netherlands

Vogt ND, Pinedo-Vasquez M, Brondízio ES, Almeida O, Rivero S (2015) Mosaic production landscapes in the Amazon Estuary: smallholder land use systems, flexibility in land-use decisions and forest transition from WWII to present. Soc Nat Resour Int J. doi:10.1080/08941920.2015.1014603

Vogt ND, Pinedo-Vasquez M, Brondízio ES, Rabelo F, Fernandes K, Almeida O, Rivero S, Deadman P, Dou Y (2016) Local Ecological Knowledge and Incremental Adaptation to Changing Flood Patterns in the Amazon Delta. Sustain Sci. doi:10.1007/ s11625-015-0352-2 [Special Issue: Sustainable Deltas: Livelihoods, Ecosystem Services, and Policy Implications]

Vörösmart CJ, Syvitski J, Day J, Sherbinin S, Giosan L, Paola C (2009) Battling to save the world's River Deltas. Bull At Sci 65:31-43. doi:10.2968/065002005

WHO World Health Organization (2003) Making a difference: indicators to improve children's environmental health: prepared by David Briggs. http://www.who.int/ceh/indicators/indicinfores/en/

WRR (2014) World risk report 2014. United Nations UniversityInstitute for Environment and Human Security (UNU-EHS), Bonn Germany and Bündnis Entwicklung Hilft Alliance. Development Works, Berlin, Germany 